\title{
TOMASZ GLUSZAK \\ Misja Kościola w Europie na progu XXI wieku. Refleksje na marginesie Adhortacji apostolskiej Ecclesia in Europa
}

Nowa rzeczywistość spoleczno-polityczna i gospodarcza jaka uksztaltowala się po dniu 1 maja 2004 r., kiedy to Unia Europejska poszerzyla się o dziesięć nowych krajów czlonkowskich (około 100 milionów obywateli) stawia przed Kościołem nowe wyzwania duszpasterskie. Ich realizacja będzie przebiegala we właściwy sposób wówczas, gdy na horyzoncie pozostanie zawsze widoczna troska o osiagniecie głównego celu posłannictwa Kościola, jakim jest doprowadzenie ludzi do zbawienia. Należy jednak pamiętać, że Kościól nie może osiagnąć wspomnianego celu, pomijając doczesny wymiar ludzkiego życia. Gloszac Ewangelię nadziei pragnie nieść pomoc w ksztaltowaniu życia spolecznego i jak przypomina II Sobór Watykański w Konstytucji duszpasterskiej o Kościele w świecie wspólczesnym Gaudium et spes: nie odwodzi ludzi od budowania świata, ani też nie zachęca do lekceważenia dobra bliźnich, lecz raczej zobowiqzuje do tego rodzaju dzialań (KDK 34).

Mając na uwadze powyższe stwierdzenie Jan Pawel II na kartach Adhortacji apostolskiej Ecclesia in Europa ${ }^{1}$ nakreślił oznaki zagubienia wspólczesnego

${ }^{1}$ Adhortacja apostolska J a n a P a w $ł$ a I I Ecclesia in Europa opublikowana została dnia 28 czerwca 2003 r. w wigilię uroczystości świętych Apostolów Piotra i Pawła. Dokument ten jest owocem dwóch Synodów Biskupów poświęconych Europie. Obrady pierwszego odbyly się w dniach od 28 listopada do 14 grudnia 1991 r., a drugiego w dniach od 1 do 23 października $1999 \mathrm{r}$. w Rzymie. Wypada ponadto zaznaczyć, że J a n P a w e 1 I I, kierując się pasterską troską o powierzony lud Boży, w minionych latach swojego pontyfikatu opublikowal już kilka adhortacji poświęconych roli i zadaniom Kościoła katolickiego na poszczególnych kontynentach. Do tak zwanych adhortacji kontynentalnych należy zaliczyć: Ecclesia in Afrika - o Kościele w Afryce i 
czlowieka przy jednoczesnym wskazaniu na znaki nadziei oraz na miejsce i rolę Kościoła w budowaniu doczesnej rzeczywistości europejskiej, która moze stać się bardziej ludzkq i bardziej pokojowa (EinE 21). W procesie tym nie może zabraknąc chrześcijan przenikniętych duchem Ewangelii, których styl życia i świadectwo pozwolą na nowo odkryć Europejczykom, że Chrystus jest przyszłościq czlowieka (EinE 20).

Papieska refleksja nad czlowiekiem i jego miejscem we wspólczesnej kulturze europejskiej oraz wizja przyszlej Europy zaprezentowana została w sześciu kolejnych rozdzialach dokumentu, podejmujacych następujące zagadnienia:

- W rozdziale pierwszym, obok charakterystycznych blasków i cieni wspólczesnej kultury europejskiej, w której czlowiek doświadcza zagubienia i niepokoju, ukazana jest Osoba Jezusa Chrystusa - źródło prawdziwej nadziei obecnej we wspólnocie wierzacych.

- Rozdzial drugi mówi o istotnej roli Kościoła w ksztaltowaniu chrześcijańskiego oblicza nowego tysiąclecia.

- Kolejne rozdzialy (trzeci, czwarty i piaty) analizują trzy charakterystyczne funkcje misji ewangelizacyjnej Kościola: prorocka, kaplańską i królewską, którym w dokumencie papieskim zostaly przyporzadkowane następujące określenia: glosić Ewangelię nadziei, celebrować Ewangelię nadziei i służyć Ewangelii nadziei.

- Szósty i zarazem ostatni rozdzial adhortacji dotyczy kluczowych kwestii odnoszących się do tworzącej się nowej Europy.

Niniejsze przedłożenie stanowi próbę ukazania w świetle adhortacji Ecclesia in Europa shużebnej roli Kościola w procesie ksztaltowania duchowego oblicza nowej Europy. Zakomunikowana tematyka przybliżona zostanie w trzech następujących częściach:

1. Społeczna, kulturowa i religijna sytuacja wspólczesnej Europy;

2. Duchowa pustka Europejczyków;

3. Zadania duszpasterskie w świetle spolecznego nauczania Kościola.

Wypada w tym miejscu także podkreślić, że w papieskiej wizji nowej Europy nie ma miejsca na jakikolwiek pesymizm czy fatalizm, na niemoc czy rozpacz wobec społecznych przemian widocznych w procesie integracji Starego Kontynentu i zjawiska ogólnoświatowej globalizacji. Jest natomiast nadzieja i ufność, że czlowiek motywowany wiarą w Jezusa Chrystusa, zawierająca niezwykly po-

jego misji ewangelizacyjnej u progu roku 2000 (1995 r.); Ecclesia in Amerika - o spotkaniu z Jezusem Chrystusem żywym, droga do nawrócenia, komunii i solidarności w Ameryce (1999 r.); Ecclesia in Asia - o Jezusie Chrystusie Zbawicielu oraz Jego misji miłości i służby w Azji (1999 r.); Ecclesia in Oceania - o Jezusie Chrystusie i ludach Oceanii (2001 r.); Ecclesia in Europa - o Jezusie Chrystusie, który żyje w Kościele jako źródło nadziei dla Europy (2003 r.). 
tencjal duchowy, kulturowy i etyczny (EinE 19), podejmie trud budowania wspólnego europejskiego domu na gruncie ewangelicznych wartości.

\section{Społeczna, kulturowa i religijna sytuacja współczesnej Europy}

Na skutek przemian ustrojowych, jakie dokonaly się w 1989 r. w związku z rozpadem porządku uksztaltowanego przez układ jaltański powstała w wielu krajach Europy Środkowo-Wschodniej pilna potrzeba budowania demokratycznego porzadku spolecznego. Wlaśnie wówczas, na przelomie lat osiemdziesiątych i dziewięćdziesiatych w sercach wielu ludzi wyzwolonych z jarzma komunizmu, zrodziła się nadzieja na lepszą przyszłość i godniejsze warunki życia. Rzeczywistość w szybkim czasie pokazala, że dokonujący się proces przeobrażeń ustrojowych nie jest latwym zadaniem i nie przebiega w taki sposób jak wielu sobie to wyobrażalo. Taki stan rzeczy zrodził w sercach pokaźnej liczby ludzi poczucie niepewności a nierzadko rozczarowanie ${ }^{2}$. Krótko po wydarzeniach roku 1989 Jan Paweł II w encyklice Centesimus annus postulowal konieczność cierpliwej odbudowy materialnej i moralnej w sytuacji domagania się natychmiastowych $i$ namacalnych rezultatów przez narody należące do dawnego Bloku Wschodniego (CA 27)

Upadek komunizmu oraz tocząca się debata nad rozszerzeniem Unii Europejskiej uświadomily mieszkańcom Europy Zachodniej, że Europa nie oznacza tylko i wylącznie ich Europy, jak dotąd byli przyzwyczajeni, ale obejmuje także mieszkańców Europy Wschodniej. Stąd dokonująca się na naszych oczach ewolucja nowoczesnej Europy pozwala uważnemu obserwatorowi odkryć, że na Starym Kontynencie istnieją niejako obok siebie dwie różne Europy:

- jedna to Europa najnowszych zdobyczy techniki, dobrobytu materialnego, pokoju oraz pewnej stabilizacji politycznej i spolecznej, a zarazem Europa zsekularyzowana, odznaczająca się nihilizmem, nieograniczonym konsumizmem, której obywatele doświadczają znudzenia i duchowej pustki;

- druga to Europa krajów nadrabiających zaległości w rozwoju; Europa ludzi ubogich często na skutek bezrobocia, dysproporcji plac czy emerytur; Europa, w której są obecne środowiska ludzi bogatych lub nowobogackich, ceniących często sukces jako absolutnie najwyższe dobro i wartość, pomijając zarazem wartości duchowe. W krajach, które wyszly z komunizmu w odniesieniu do

\footnotetext{
${ }^{2}$ Por. J.Y. C a 1 v e z: Upadek komumizmu W: Chrześcijaństwo a integracja europejska. Thum. H. P a w li k ow sk a - Ga n n o n. Kraków 1997 s. 199.
} 
wspomnianych środowisk wylania się problem nieograniczonej żądzy szybkiego zysku, kosztem innych ${ }^{3}$.

Transformacji ustrojowej i zmianom w systemie społeczno-gospodarczym towarzyszyl proces integracji kontynentu europejskiego. W pewnym sensie zwieńczeniem wspomnianego procesu byl fakt przystapienia dziesięciu państw, w tym Polski, do Unii Europejskiej. W świetle badań socjologicznych fakt ten lączy się z nowymi zadaniami, wobec których nie tylko stanie Kościól, ale którym będzie musiał sprostać w wymiarze misji ewangelizacyjnej ${ }^{4}$.

Uwzględniając powyższe spojrzenie na Europe warto uzmyslowić sobie glówne problemy nękające wspólczesnych Europejczyków, żyjacych tak na Wschodzie jak i Zachodzie kontynentu. Jan Pawel II określa te problemy mianem gaśnięcia nadziei (EinE 7-9). Co sklada się zatem na wspomniane gaśnięcie nadziei?

Autor adhortacji, podejmując analizę wspólczesnej rzeczywistości społecznej, wyszedl od stwierdzenia, że obecne czasy to okres zagubienia (EinE 7). Jest on wynikiem poglębiającego się od lat kryzysu uksztaltowanej przez starożytną myśl grecka, prawo rzymskie, judaizm i chrześcijaństwo cywilizacji euroatlantyckiej. Kryzys ten stopniowo narastal od czasów Oświecenia, uwidaczniając się szczególnie w wydarzeniach rewolucji studenckiej z drugiej polowy lat sześćdziesiatych, która swym zasięgiem objęla wówczas kraje Europy Zachodniej. Poczynając od relatywizacji wartości, w tym prawdy, poprzez trwający do dziś proces uwalniania się czlowieka od Boga i chrześcijaństwa, doprowadzil on w konsekwencji do zmiany wizji świata i koncepcji czlowieka ${ }^{5}$. O tych przeobrażeniach precyzyjnie wyraził się Jan Paweł II, gdy napisal: Jesteśmy świadkami narodzin nowej kultury (...), której cechy charakterystyczne i treści często sprzeczne sq z Ewangeliq i z godnościq osoby ludzkiej (EinE 9). Do oznak tej nowej kultury, której rysem znamiennym staje się niewiara, papież zalicza takie zjawiska, jak: utrata pamięci i dziedzictwa chrześcijańskiego, zeświecczenie, lęk przed przyszlościa widoczny zwlaszcza w dramatycznym spadku liczby urodzeń, fragmentaryzacja egzystencji, coraz mniej przejawów prawdziwej solidarności

${ }^{3}$ Por. M. Mc K e e ve r: Kościól w Europie - w poszukiwaniu klucza do lektury adhortacji Jana Pawla II. Thum. W. Zag rodzki. „Homo Dei” R. 74: 2004 nr 4 s. 14; J. Ż y c ińs k i: Nowe wyzwania duszpasterskie w perspektywie budowania duchowej jedności Europy. W: Naśladować Chrystusa. Program duszpasterski na rok 2003/2004. Katowice 2003 s. 29.

${ }^{4} \mathrm{~W}$ kwestii przystapienia Polski do Unii Europejskiej, polowa badanych jednoznacznie ocenia, że wejście w struktury zjednoczonej Europy stanowi dla Kościola nowe zadania, a dla 16,2\% ludzi nowe zagrożenia (Kościól katolicki na poczatku trzeciego tysiaclecia w opinii Polaków. Red. W. Z d a n i e w i c z, S. H. Z a r e b a, Warszawa 2004 s. 199).

${ }^{5}$ Por. S. W i e lg u s: Ideowy obraz wspólczesnej kultury euroatlantyckiej. W: Bogu i Ojczyźnie. Uniwersyteckie przemówienia i listy 1996 -1998. Red. J. Mi c halczy k. Lublin $1999 \mathrm{~s}$. $149-150$ 
międzyludzkiej, dążenie do narzucenia antropologii bez Boga, zawężenie nadziei do rzeczywistości ziemskiej (EinE 7-10). Wymienione zjawiska są efektem złożonego procesu lączącego się z obejmującą coraz szersze kręgi spoleczne laicyzacja, której źródeł należy dopatrywać się we wplywach humanizmu pogańskiego i rozmaitych nurtów filozoficznych, zwłaszcza oświeceniowego racjonalizmu, doprowadzających do sporu o koncepcję człowieka. Ponadto istotny wplyw na wspomniany proces wywierają również postawy samych chrześcijan, których coraz częściej dotyka zjawisko obojętności religijnej, a w konsekwencji zagubienie na polu etyki oraz ateizm praktyczny i egzystencjalny. Jest to wynik postępującego sekularyzmu, który wplywając na postawy ludzkie, a w konsekwencji na życie społeczne, stopniowo przebiega - jak stwierdził J. Mariański - od procesu odkościelnienia (deinstytucjonalizacja religii), poprzez dechrystianizację, prowadząc ostatecznie do bezreligijności ${ }^{6}$.

R. Buttiglione i J. Merecki zwracaja uwage na dwa etapy sekularyzacji chrześcijańskiej Europy. Pierwszy lacczy się z oświeceniowym racjonalizmem, który odrzucil nadprzyrodzony wymiar chrześcijaństwa, zachowując jednak wszelkie wartości odkryte i wniesione przez nie do europejskiej kultury. Drugi etap, nierozerwalnie zlączony z postmodernizmem, prowadzi do zaniku nie tylko chrześcijańskiej wiary, ale samego chrześcijaństwa jako elementu kultury. Ta faza sekularyzacji zmierza coraz skuteczniej do wykreowania nowej cywilizacji świata pochrześcijańskiego ${ }^{7}$.W upowszechnianiu się tzw. świata pochrześcijań-

${ }^{6}$ Por. J. Mariań ski: Co mówi „Duch czasu” - sekularyzacja religii i spoleczeństwo postsekularne. „Roczniki Nauk Spolecznych”. T. 32: 2004 z.1 s. 50.

${ }^{7}$ Por. R. B ut tig 1 i o n e, J. M e r e c k i: Chrześcijaństwo jako podstawa wspólnego europejskiego domu. W: J a n P a wel I I: Centesimus annus. Tekst $i$ komentarze. Red. F. K a m p ka, C. R it t e r. Lublin 1998 s. 112-113. W podobnym duchu snuje refleksję J. G o c k o, gdy pisze na temat posłannictwa Kościola w świecie w konfrontacji z sekularyzmem i kryzysem wspólczesnej cywilizacji: Zjawiska te należy widzieć w szerszym kontekście aktualnych problemów wspólczesnego świata, w którym coraz powszechniej mówi się o kryzysie spoleczenstw rozumianym jako koniec ery nowożytnej wraz z jej recjonalizmem $i$ scjentycyzmem, a jednocześnie jako poczatek czasów posthistorycznych i posthumanistycznych. Tak zwany ,przelom postmodernistyczny” oznacza odejście od dotychczasowego modelu życia i porzadku spolecznego oraz odrzucenie dotychczasowego systemu aksjologicznego. Zwiazane $z$ nim jest również podważenie tradycyjnego znaczenia instytucji $i$ zakwestionowanie autorytetów urzędowych. Nie dziwi w tym kontekście swoiste rozejście sie religii czy wartości nadprzyrodzonych i zycia doczesnego. W zwiazku z tym sekularyzm, będacy jednym z elementów postmodernizmu, staje się $w$ rzeczywistości antyewangelia. Laczy się to z próba pozbawienia orędzia chrześcijańskiego profetyczno-krytycznego charakteru, a takize z odrzuceniem misji ewangelizacyjnej realizowanej przez Kościól w świecie (J. Go c k o: Kościól obecny $w$ świecie - poslany do świata. Teologiczno-spoleczne aspekty postannictwa Kościola $w$ świecie po Soborze Watykańskim II. Lublin 2003 s. 337). Mówiąc o kryzysie kultury europejskiej podobne wręcz stwierdzenie wysuną także kard. J. R a t z ing e r. Zauważył on proces wyraźnego przechodzenia historii ostatnich wieków w nowy świat, którego życie publiczne opanowane jest w dominującym stopniu przez nurty myśli calkowicie świeckiej (J. R a t z in g e r: Duchowe funda- 
skiego, czy jak sugeruje Jan Paweł II nowej kultury, pomagaja coraz silniej oddzialywujące mass media, narzucając określone modele, schematy i wzorce zachowań. Presja kultury masowej z nadmiarem informacji sprawia, że człowiek często gubi się we wlaściwym rozeznaniu rzeczywistości i jej trafnej ocenie, przejmujac w tej sytuacji poglady opinii publicznej. Nie bez wplywu pozostaje także zjawisko subiektywizacji wiary połączone $\mathrm{z}$ obojętnością religijna wielu chrześcijan i ich niekonsekwencje w życiu praktycznym, widoczne w deformacji idealów ewangelicznych. Wielu ludzi - napisał Jan Pawel II - nie potrafi już lqczyć ewangelicznego przestania z codziennym doświadczeniem [...], odnosi się wrażenie, że niewiara jest czymś naturalnym, podczas gdy wiara wymaga uwierzytelnienia spolecznego (EinE 7).

Ta nowa, będąca pod wplywem wielkich prądów myśli laickiej kultura, zwana kulturą bez Boga, czy też kulturą neopogańska, odrzuca chrześcijańską inspirację i na wzór starożytnego pogaństwa gloryfikuje coraz powszechniej dewiacje moralne, kult sily, wladzę, pieniądze. Kościól z Dobrą Nowina o zbawieniu a wraz $z$ nim chrześcijaństwo zostaje spychane w spoleczeństwie ponowoczesnym na margines życia spolecznego, co skutecznie oslabia inspirujący wplyw Ewangelii na ksztalt życia publicznego i kulturę obywatelską. Stąd wypada zgodzić się z trafnym, chociaż bolesnym, stwierdzeniem B. Sorge: Kościól $i$ chrześcijanie dzisiaj stanowiq skromna mniejszość w spoleczeństwie i kulturze szeroko zdechrystianizowanej i neopogańskiej ${ }^{8}$.

W analizie aktualnych przeobrażeń i kierunków rozwoju nadających bieg współczesnym społeczeństwom oraz w ocenie najważniejszych problemów spolecznych papież podkreśla także nową postać zagrożeń ludzkości, wylaniająca się $\mathrm{z}$ upowszechniania się tendencji subiektywistycznych, utylitarystycznych $i$ relatywistycznych (VS 106). Wspomniane tendencje przejawiaja się w rozdzieleniu

menty Europy wczoraj, dziś i jutro. Tłum. P. B o r k o w s k i. „Spoleczeństwo”. R. 14: 2004) nr 4-5 s. 649-650).

${ }^{8}$ B. S org e: Wyklady z katolickiej nauki spolecznej. Od Ewangelii do cywilizacji milości. Thum. M. Z a r ę b a. Kraków 2001 s. 118. Warto w tym miejscu zapoznać się z trzema podanymi przez J. K r u c in ę czynnikami, które eliminuja wplyw chrześcijaństwa na życie publiczne: Francuskie Oświecenie, tak poczatkowo intrygujace, należy do trzech czynników, które wypieraja, przede wszystkim przez bezbożny racjonalizm, chrześcijaństwo z życia publicznego. Po drugie: proces dewastujacej swawoli wraz z eliminacja religii mial przyspieszać marksistowski szturm rewolucji proletariackiej, który wprawdzie przegral, ale jego skutki nie sa jeszcze wytrzebione. Po trzecie: panoszaca się wieża postępu, technicznych osiagnięć, choć przechylona, choćby na skutek nadprodukcji, wabi hedonizmem, ale $i$ apatyczna obojętnościq, która $w$ poczuciu bezsensu stacza ludzi do aberracji sekt a nawet depresji (J. K r u c in a: Co mówi Papież. Nauczanie spoleczne Jana Pawla II. Wrocław 2005 s. 262). 
prawdy od wolności oraz wiary od moralności ${ }^{9}$. Konsekwencja tego faktu, czy też używając określenia Jana Pawła II religijności mglistej i niejednokrotnie blędnej (EinE 68), są przemiany widoczne coraz wyraźniej na plaszczyźnie obyczajowej, w relacjach interpersonalnych, w postawach i wzorach zachowań spolecznych, w moralności życia publicznego i życia codziennego. Stąd autor Ecclesia in Europa z niepokojem stwierdzi: Dzisiejsza Europa, w tym samym czasie, gdy umacnia i poszerza swq jedność gospodarczq i politycznq, przeżywa-jak się zdaje - glęboki kryzys wartości (EinE 108). Nieco dalej, mówiąc na temat procesu integracji kontynentu oraz trudu budowania Europy wartości i prawa (EinE 115) Jan Pawel II po raz kolejny podkreślil, że tworzona $z$ wysilkiem jedność europejska nie będzie trwała, jeśli zostanie zredukowana tylko i wylącznie do wymiaru geograficznego, politycznego i ekonomicznego - musi ona polegać przede wszystkim na harmonii wartości (EinE 110).

Do grupy wartości podstawowych zaszczepionych w kulturę Europy przez chrześcijaństwo i majacych fundament w prawie naturalnym oraz cieszących się powszechną akceptacją należy zaliczyć: godność osoby ludzkiej, poszanowanie życia, wolność, sprawiedliwość, równość, solidarność, tolerancję, pokój. Odrzucenie wymienionych wartości w imię jakichkolwiek racji sprawi, że prędzej czy później trud budowania wspólnego europejskiego domu okaże się daremnym, a jedność Europy skazana będzie na niepowodzenie i dramatyczną klęskę.

Na polu nauki spolecznej Kościoła truizmem jest twierdzenie, że od koncepcji czlowieka zależy koncepcja spoleczeństwa. W życiu spoleczno-kulturo- wym współczesnej Europy obok antropologii podkreślającej wielkość czlowieka w perspektywie Boga (istotna rola aktu stworzenia i odkupienia), istnieje drugi rodzaj antropologii, uznającej czlowieka za jedyny punkt odniesienia, za poczatek i koniec wszystkich rzeczy oraz miarę własnej wielkości. Koncepcja ta zaklada wyeliminowanie Boga z życia człowieka, co zawsze ostatecznie skieruje się przeciwko samemu czlowiekowi, czego dowodem sa zrodzone w XX w. dwa okrutne totalitaryzmy ${ }^{10}$. W nieco podobnym duchu można spojrzeć na fakt podpisania Traktatu Konstytucyjnego w październiku 2004 r. w Rzymie, gdzie jego twórcom zabraklo woli umieszczenia odniesienia do duchowych korzeni kultury europejskiej i dziedzictwa religijnego, zwlaszcza chrześcijaństwa, o co zabiegal i niejednokrotnie apelowal Jan Pawel II także na kartach Ecclesia in Europa (por. EinE 114).

\footnotetext{
${ }^{9}$ Szerzej na ten temat zobacz W. Ś w i ąt k i e w i c z: Znaczenie religijności dla wspólczesnych przemian spolecznych na Górnym Slasku. W: Kultura i religia u progu III Tysiaclecia. Red. W. Ś w i a t k i e w i c z, A. P e th e. Katowice 2001 s. 63-76.

${ }^{10}$ Por. H. Mu s z y ń s k i: Whlad Kościola w budowanie jedności duchowej Europy. „Społeczeństwo". R. 13: 2003) nr 6 s. 941.
} 
W panoramie życia spolecznego na kontynencie europejskim dostrzega się dziś nie tylko obecność dwóch przeciwstawnych antropologii, ale także upowszechnianie się dwóch odmiennych koncepcji wolności. Jedna lączy się z akceptacją niezmiennych norm etycznych, mających źródlo w prawie naturalnym i Objawieniu, druga przeciwnie, nie akceptuje tych norm, co w konsekwencji prowadzi do relatywizmu zarówno w życiu osobistym jak i społecznym ${ }^{11}$.

Z kolei w ważnej dla życia spolecznego dziedzinie polityki uwidaczniają się nierzadkie przypadki korupcji politycznej, które niejednokrotnie są przyczyną groźnych form niesprawiedliwości spolecznej, a nawet prowadzą do afer gospodarczych na szeroką skalę.

Warto w tym miejscu zaznaczyć, że w ostatnich latach, zwlaszcza w Polsce, narastalo szczególne zainteresowanie katolicką nauką spoleczną ze strony przedstawicieli różnych partii politycznych, którzy w programach wyborczych powolywali się na zasady wypracowane przez tę naukę, często w celu pozyskania większego elektoratu. Praktyczne działania ukazaly, że nie kierowano się jednak inspiracja chrześcijańsko-spoleczną w duchu wspomnianej nauki.

Ta niepelna panorama problemów natury spolecznej, kulturowej i religijnej zrodzonych $\mathrm{z}$ przemian zachodzących w spoleczeństwie Europy pokazuje, że Europejczycy coraz częściej myślą i postępują po pogańsku, a ich życie nacechowane jest konsumizmem, erotyzmem, dominowaniem postawy mieć nad być, co w skutkach niejednokrotnie prowadzi do zamykania się na rzeczywistość transcendentną i zatracania glębszego sensu życia. Tak więc upowszechnianie się cywilizacji o profilu materialistycznym, technicznym i konsumpcyjnym prowadzi do deprecjonowania kultury duchowej, co wydaje się być - jak zauważa T. Borutka-najważniejszym niebezpieczeństwem współczesnej cywilizacji ${ }^{12}$.

Wielu ludzi z prawdziwą satysfakcją mówi dziś o chorobach i bolączkach nękających wspólczesną Europę, tymczasem papież Jan Paweł II, mówiąc o nich i znając ich przyczyny, podkreśla, że naszym zadaniem - jako chrześcijan - jest budowanie wspólnego europejskiego domu na systemie wartości wypracowanych w oparciu o Ewangelię i tradycję chrześcijańską. Podejmując realizację tego zadania należy uwzględnić także obecność znaków nadziei zarówno w rzeczywistości Kościola, jak i w rzeczywistości społeczności cywilnej wspólczesnej Europy. Świadczą one o sile ludzkiego ducha, który nie może żyć bez ukierunkowanych ku przyszłości perspektyw (EinE 11-13).

\footnotetext{
11 Por. M. S tę p n i a k: Kościolowi w Europie napisz... Kielce 2004 s. 29.

${ }^{12}$ T. B o r u t k a: Spoleczne nauczanie Kościola. Teoria i zastosowanie. Kraków 2004 s. 286.
} 


\section{Duchowa pustka Europejczyków}

Jedna $\mathrm{z}$ przeszkód $\mathrm{w}$ realizacji zadania tworzenia Europy ducha jest pustka duchowa znacznej części mieszkańców Starego Kontynentu. Procesy transformacji ustrojowej unaocznily ze szczególną wyrazistością powszechność tego zjawiska. Należy jednak zauważyć, że w krajach Europy Srodkowo-Wschodniej jest ono w jakimś stopniu, jak stwierdził Jan Pawel II, efektem ateizmu (CA 24), a w krajach Europy Zachodniej praktycznego materializmu, który pobudzając do konsumpcji pozostawia w ludzkiej świadomości pustkę oraz prowadzi do przyjęcia postawy znudzenia i zaniku duchowych sił. Fakt wewnętrznego zubożenia uwidacznia się zwlaszcza w problemie demograficznym. Europejczykom brakuje woli przyszlości, albowiem często nowe ludzkie życie traktuje się jako ograniczenie w teraźniejszości, przez co Europa zdaje się etnicznie wygasać ${ }^{13}$. Zalamanie się przyrostu naturalnego $\mathrm{w}$ Europie wyraźnie dostrzegalne od lat siedemdziesiatych minionego wieku przybiera znamię katastrofy demograficznej w pelnym tego slowa znaczeniu. W latach bowiem dziewięćdziesiątych w krajach czlonkowskich Unii Europejskiej było rocznie prawie o 2 miliony mniej urodzeń niż zgonów ${ }^{14}$. Ponadto na to zjawisko wypada spojrzeć w perspektywie kultury techniczno-konsumpcyjnej, która znacznie więcej uwagi i sil poświęca technologiom coraz to nowych generacji multimediów niż antropologiczno-filozoficznej refleksji. W rzeczywistości odrzucenia Boga, w erze technizacji świata, sukcesów gospodarczych oraz konsumpcji nie może dziwić fakt marginalizacji osoby ludzkiej, który z bolesna wyrazistościa odsłania nie tylko obniżenie wartości ludzkiego życia, ale zamknięcie się na dar nowego życia, co ukazuje przedziwna wręcz martwicę duszy ${ }^{15}$. Ta sytuacja sprawia, że dzisiejszy czlowiek, podejmujac trud budowania doczesnej rzeczywistości pomija często ewangeliczne (transcendentne) wartości, a w ich miejsce stawia poniekąd najważniejszą wartość - wlasną egzystencję, której jednak nie potrafi nadać pelnego i trwalego sensu. Stąd wielu wspólczesnych Europejczyków ucieka w świat doznań, przyjemności, iluzji, nieograniczonej konsumpcji, szukając zadowolenia w skończoności, co tak naprawdę stanowi źródlo ich wewnętrznej rozpaczy. Ludzie ci nie wiedzq, w jaki sposób można dokonać odwrotu od przyjętego przez siebie dobra przemijającego i zwrócenia się do dobra nieprzemijajacego ${ }^{16}$.

Warto w tym miejscu zapoznać się z myślą J. Gowina, który wskazuje na dwa powody sprzyjajace upowszechnianiu się coraz bardziej postaw konsumpcjonistycznych. Postawy te bowiem sa prawdziwym zagrożeniem dla wiary. $Z$

${ }^{13}$ Por. J. R a $\mathrm{t}$ z in g e r: Duchowe fundamenty Europy wczoraj, dziś i jutro..., dz. cyt., s. 651.

${ }^{14}$ J. K 1 o c z o w s k i: Europa. Chrześcijańskie korzenie. Warszawa 2004 s. 197.

${ }^{15}$ J. J e d l i c k i: Trzy wieki desperacji. „Znak”. R. 48: 1996 nr 1(488) s. 19.

${ }^{16} \mathrm{M}$. Mró z: Między zuchwalstwem a rozpacza: Odpowiedź etyki nadziei na pytanie o przyszlość katolicyzmu polskiego $i$ wiary w Europie. Katolicyzm polski w warunkach Unii Europejskiej: Szanse i zagrożenia, obawy i nadzieje. „Socjologia Religii”. T. 2: 2004 s. 39. 
jednej strony konsumpcjonizm promuje wizję życia ludzkiego ograniczonego do potrzeb materialnych $z$ wyeliminowaniem potrzeb duchowych, a $z$ drugiej strony propaguje wzorzec życia ulatwionego. Cywilizacja ulatwień, charakterystyczna dla naszych czasów, przenikając do sfery duchowej czlowieka, sprzyja szerzeniu się i upowszechnianiu wśród wierzących postaw selektywnych, również w odniesieniu do rzeczywistości wiary ${ }^{17}$.

Dzisiaj wielu mieszkańców Europy nie stawia sobie bezpośrednio zasadniczych pytań o wlasne pochodzenie: Skąd pochodzę? i Dlaczego istnieję?, ani też o ostateczne przeznaczenie: Doką zmierzam? i Co stanie się ze mna po śmierci? Jednak naturalna siła lęku przed unicestwieniem rozbudza w czlowieku namiastkę tęsknoty lub prawdziwą tęsknotę za ,jakaś" religią. Odejście od osobowego Boga, a zarazem doświadczenie pustki duchowej odslania pewna „mglistą" wrażliwość czlowieka na świat nadprzyrodzony. W latach siedemdziesiątych, osiemdziesiatych i dziewięćdziesiatych minionego wieku można bylo dostrzec, zarówno pośród mieszkańców Wschodu jak i Zachodu, niezwykle dynamiczny rozwój rozmaitych kultów religijnych, w których nie było jednak mowy o osobowym Bogu. Odrzucenie prawdziwej religii niosącej dar zbawienia, wiąże się nieodlącznie $z$ rozwojem falszywych religii, groźnych ruchów pseudoreligijnych o zbrodniczych kultach, sekt, magii, okultyzmu, wiary w zbawcza moc horoskopów, jasnowidzów i psychoterapeutów ${ }^{18}$. Opisany stan rzeczy ukazuje, że natura ludzka nie znosi pustki, dlatego czlowiek poszukuje zaspokojenia duchowego glodu w pseudoreligijnych ruchach, narkotykach, pornografii, konsumizmie (CA 36).

Do upowszechniania się opisanych zjawisk przyczyniaja się w pewnym stopniu media, które, oddzialywując obrazem pelnym reklamy, przemocy i erotyzmu, rozbudzaja u bezkrytycznego odbiorcy nierealne pragnienia i marzenia, wplywaja na rozwój i dominowanie postawy mieć nad być, przyczyniaja się do pasywności, nieumiejętności organizowania czasu i panowania nad nim oraz niedorozwoju indywidualnych zainteresowań i uzdolnien ${ }^{19}$. Bezkrytyczny i bierny odbiorca zatraca zdolność samodzielnego myślenia, krytycznej oceny rzeczywistości, twórczej postawy. Jan Pawel II, mówiąc o narodzinach nowej kultury, wskazal na istotny jej związek ze światem mediów masowych: Jesteśmy świadkami narodzin nowej kultury, pozostajqcej w znacznej mierze pod wplywem środków masowego przekazu (EinE 9). Wypada zauważyć, że to właśnie media, jako

${ }^{17}$ Szerzej na ten temat zobacz J. G o w i n: Zadania Kościola w czasach wolności. W: Nowa ewangelizacja u progu Trzeciego Tysiaclecia. Program duszpasterski na rok 2000/2001. Katowice 2000 s. 73.

${ }^{18}$ Por. Z. Z d y b i c k a: Rola religii w kulturze wspótczesnej. W: Kultura i religia u progu III Tysiaclecia..., dz. cyt., s. 18; S. W i e $1 \mathrm{~g}$ u s: Ideowy obraz wspólczesnej kultury euroatlantyckiej..., dz. cyt., s. 150

${ }^{19}$ Por. L. D y c z e w s k i: Kultura polska w procesie przemian. Lublin 1995 s. 169-170. 
nieodlączny wręcz element codziennego życia, w znacznym stopniu przyczyniaja się do kreowania rzeczywistości i upowszechniania określonych modeli życia.

\section{Zadania duszpasterskie w świetle społecznego nauczania Kościoła}

Uwzględniajacc zarysowaną wizję europejskiej rzeczywistości, którą tworza przecież także chrześcijanie w Polsce, latwiej dostrzec wyłaniające się przed Kościolem zadania w dobie budowania Europy ducha. Refleksja nad papieskim nauczaniem zawartym w adhortacji Ecclesia in Europa pozwala bowiem na odkrycie i uwzględnienie w duszpasterskiej działalności Kościola, a w konsekwencji na podjęcie stosownych inicjatyw pastoralnych w odniesieniu do następujacych zagadnien:

\section{Ukazywanie poprawnej, integralnej i pelnej koncepcji osoby ludzkiej}

Dziś w dobie deteologizacji osoby ludzkiej coraz częściej patrzy się na czlowieka w wymiarze doczesności, pomijając jego wymiar nadprzyrodzony. Człowieka ukazuje się najczęściej jako tego, który zadowala się dobrami skończonymi i nadziejami doczesnymi. Nie dostrzega się w nim osoby posiadającej niezatarte znamię transcendentnej godności, ale konsumenta na wielkiej arenie rynku. Media, reklama, prasa, banki, biura turystyczne, wielkie koncerny przemyslowe przy pomocy rozmaitych metod, zabiegów i apeli czynią wiele starań, by czlowiek coraz to więcej konsumowal. Podpowiadaja, jak należy się odżywiać, gdzie atrakcyjnie wypoczać, jak wyposażyć mieszkanie, w co należy się ubrać. Tak więc logika rynku, ziemskiego szczęścia i dobrobytu wypromowata antropologię "mieć", które wytwarza czlowieka interesu, a zdyskwalifikowata antropologie bycia, które ksztaltuje czlowieka zasad ${ }^{20}$. W skutkach prowadzi to do upowszechniania się redukcjonistycznej wizji osoby ludzkiej sprowadzonej w najbardziej radykalnych materialistycznych nurtach współczesnej myśli do zwyklej czasstki przyrody. Efektem takiego naturalistycznego rozumienia czlowieka jest obecnie wzrostowa tendencja do apoteozy ludzkiej cielesności przy jednoczesnym deprecjonowaniu pierwiastka duchowego. Obraz czlowieka stworzony przez filozofie czasów nowożytnych i wspólczesnych, pozbawia często osobę ludzką wymiaru duchowego, w przeciwieństwie do teorii wypracowanych przez starożytnych i średniowiecznych myślicieli, którzy w swoich dociekaniach nade wszystko podkreślali duchowy wymiar bytu ludzkiego ${ }^{21}$.

${ }^{20}$ I. S a n n a: Wyzwania dla antropologii chrześcijańskiej w czterdzieści lat po „Pacem in terris”. Tłum. T. Ż e leźn i k. „Spoleczeństwo”. R. 13: 2003 nr 6 s. 821

${ }^{21}$ Por. I. D e c: Jaka wizja czlowieka dla nowej Europy? W: Europa. Zadanie chrześcijańskie. Red. A. Dy l u s. Warszawa 1998 s. 344. 
W niedawnej przeszlości praktyczną konsekwencją filozofii, które odmawiając czlowiekowi wymiaru nadprzyrodzonego uprzedmiotowily go, byly tragiczne doświadczenia minionego stulecia. Pokazaly one wyraźnie, iż dyktatorzy dwudziestowiecznych totalitaryzmów (hitleryzmu - wyroslego na bazie filozofii Nietzschego, która gloszac śmierć Boga postawila w Jego miejsce tzw. nadczlowieka i ateistycznego marksizmu - który chcac zlikwidować nierówności spoleczne zastosowal jako metodę pelną nienawiści walkę klas i rewolucję) uzurpowali sobie Boskie prawo do decydowania o życiu lub śmierci milionów niewinnych istnień ludzkich. Odrzucenie bowiem osobowego Boga zarówno z życia indywidualnego jak i zbiorowego skieruje się zawsze przeciwko samemu czlowiekowi.

W tej perspektywie, jak również w rzeczywistości zderzenia się dwóch przeciwstawnych antropologii, o czym wspomniano już w pierwszej części artykulu, rodzi się potrzeba przedstawiania prawdy o czlowieku odkrywanej zarówno na drodze filozoficznej refleksji, jak i w świetle Bożego Objawienia. Teorie filozoficzne stanowia bowiem często konkretne programy działania realizowane w życiu $^{22}$. Ponadto rozwikłanie tajemnicy czlowieka w znacznym stopniu przyczynia się także do nadania życiu spolecznemu prawidlowego ksztaltu. Stąd przed Kościolem wylania się, jako jedno z pierwszorzędnych zadań ewangelizacyjnych, ukazywanie poprawnej, integralnej i pelnej koncepcji osoby ludzkiej, stworzonej przez Boga i mającej w Nim ostateczny cel. Chrześcijańska antropologia podkreśla bowiem wartość niezbywalnej godności osoby ludzkiej, która nie jest niczym innym, jak wrodzonym i naturalnym znamieniem czlowieka. Jan Pawel II w Orędziu do biskupów w Puebla w 1979 r. powiedzial: godność czlowieka stanowi wartość ewangeliczna, której nie można naruszyć nie obrażając głęboko Stwórcy ${ }^{23}$.

Kościól w swoim nauczaniu, mówiąc o godności człowieka rozpatruje ją w aspekcie przyrodzonym i nadprzyrodzonym. W plaszczyźnie przyrodzonej wspomniana godność wyraża się w stworzoności czlowieka na obraz i podobieństwo Boże $(\operatorname{Rdz} 1,27)$, a w konsekwencji w uznaniu go za koronę calego stworzenia. Magisterium Kościola podkreśla ponadto, że czlowiek jest jedynym na ziemi stworzeniem, którego Bóg chcial dla niego samego (KDK 24). Oznacza to, że Bóg stworzył czlowieka $z$ milości, jako jedyną i niepowtarzalną osobę wyposażona w rozum i wolna wolę. Atrybuty te decyduja o odpowiedzialności człowieka za podejmowane decyzje i czyny. Taka wizja ukazuje zatem niepowtarzalną wartość każdego bez wyjątki czlowieka, której żadna wręcz instancja nie jest

\footnotetext{
${ }^{22}$ Por. S. W i e lg u s: Rodzina wobec wspólczesnych zagrożeń. W: Bogu i Ojczyźnie..., dz. cyt., s. $166-167$.

${ }^{23}$ J an P awe 1 I I: Orędzie do biskupów w Puebla, 28. 01. 1979. W: Dokumenty nauki spolecznej Kościola. Red. M. Radwan, L. Dy czewski, A. Stanowski. Cz. II. RzymLublin 1987 s. 15.
} 
go w stanie pozbawić. Czlowiek, ponieważ zostal stworzony na obraz Boży, posiada godność osoby: nie jest tylko czymś, ale kimś. Jest zdolny poznawać siebie, panować nad soba, w sposób dobrowolny dawać siebie oraz tworzyć wspólnotę $z$ innymi osobami (KKK 357). Tak rozumiany czlowiek przerasta cala otaczająca rzeczywistość. Jako osoba nie może być on zawłaszczany przez żadną instytucję, ani też przez żadną osobę wykorzystany. Uwzględniając powyższe wywody nie trudno nie zauważyć, że w odniesieniu do osoby ludzkiej trzeba i należy mówić o jej niepowtarzalnej i najwyższej wartości, określanej mianem godności osobowej.

Jak godność naturalna ma źródło w fakcie ukonstytuowania w człowieku przez Boga-Stwórcę podmiotowości osoby, tak nadprzyrodzona godność stanowi rezultat odkupieńczego dziela Jezusa Chrystusa. Mówiąc o tym wymiarze godności należy podkreślić wyniesienie czlowieka do godności przybranego synostwa Bożego, dziecięctwa Bożego i przeznaczenia do udzialu w życiu samego Boga. Jan Paweł II w encyklice Redemptor hominis pouczyl, że tajemnica Odkupienia ogarnięty jest każdy, rzeczywisty, konkretny, historyczny i caly czlowiek. Chodzi więc - napisal papież - o czlowieka $w$ calej jego prawdzie, w pelnym jego wymiarze (RH 13). Papieski pogląd na czlowieka obecny od ponad ćwierć wieku w teologicznej refleksji Kościola zawiera niekwestionowaną prawdę o potrzebie integralnego ujmowania osoby ludzkiej, jako jedności cielesno-duchowej. Wszelkie próby rozdzialu rzeczywistości cielesnej i rzeczywistości duchowej w czlowieku prowadzą do wykreowania blędnej, zawężonej koncepcji osoby ludz$\mathrm{kiej}^{24}$. Stąd Jan Pawel II w encyklice Centesimus annus postulowal: Należy się kierować integralnq wizja człowieka, która ogarnia wszystkie wymiary jego istnienia i która wymiary materialne i instynktowne podporzqdkowuje wewnętrznym i duchowym (CA 36).

W tym miejscu może zrodzić się pytanie: Dlaczego tak ważna jest wizja czlowieka? Odpowiadając, należy stwierdzić, że wizja czlowieka ma decydujące znaczenie dla koncepcji spoleczeństwa. Stąd spór o przyszly ksztalt Europy w dobie jej integracji jest sporem o wizję czlowieka. W tym wlaśnie względzie chrześcijaństwo ma do zaoferowania Europie antropologię ukazujaca czlowieka jako obraz i podobieństwo Boga, jako istotę prawdziwie wolną i zarazem zdolna i powołana do miłości, jako istotę posiadająca niezbywalna godność od chwili poczęcia aż do naturalnej śmierci. Ponadto chrześcijańska antropologia nie może pomijać prawdy o świętości każdego ludzkiego życia i jego nienaruszalności oraz o powolaniu czlowieka. Trzeba przyznać, że taka wlaśnie koncepcja osoby ludzkiej, pośród rozmaitych ujęć wspólczesnej antropologii nie ma sobie równej,

${ }^{24}$ Por. T. G 1 u s z a k: Redukcjonizm antropologiczny marksizmu. Dziesiata rocznica ogloszenia encykliki „Centesimus annus”. W: Ad sapientiam cordis. Red. P. Podeszwa, W. S z c z e r biński Gniezno 2002 s. 542-546. 
kontrastuje ona bowiem zarówno $\mathrm{z}$ redukcjonistycznymi antropologiami minionego marksizmu, jak i obecnego konsumizmu.

Ukazywanie poprawnej antropologii jest dziś bardzo potrzebne, by uniknąc tragicznych blędów przeszlości oraz budować nowy, wspólny europejski dom, w którym wlaściwe struktury społeczno-polityczne slużyly będą dobru pojedynczego czlowieka i dobru całej ludzkości. Stąd w misję ewangelizacyjną Kościoła wpisuje się nie tylko gloszenie poprawnej koncepcji osoby ludzkiej, ale także obrona jej godności i niezbywalnych praw. Zadaniem Kościoła w zsekularyzowanej rzeczywistości Europy i nieprzychylnej kulturze doznań pozostaje zatem slużba na rzecz promocji czlowieka i propagowanie antropologii relacyjnej ${ }^{25}$, której istota jest przekraczanie wlasnego egoizmu, by pelniej urzeczywistniać idee altruizmu wyrosłego na fundamencie przykazania milości.

\section{Ukazywanie prawdy o malżeństwie i rodzinie}

Nauka Kościoła na temat malżeństwa i rodziny odwoluje się w pierwszym rzędzie do Objawienia, w tym celu, by odczytać zamysl Boży względem tej ważnej rzeczywistości ludzkiego życia. Mając na uwadze powyższe stwierdzenie oraz korzystając $z$ wypracowanej przez II Sobór Watykański refleksji teologicznej na temat malżeństwa i rodziny zawartej w Konstytucji duszpasterskiej o Kościele w świecie wspólczesnym Gaudium et spes, a także uwzględniając poglębione spojrzenie na malżeństwo zaprezentowane w encyklice Pawla VI Humanae vitae, Jan Pawel II zachęcil Kościól w Europie, by w realizacji swojej duszpasterskiej działalności nie tylko wiernie glosil prawdę o małżeństwie i rodzinie, ale także stanowczo potwierdzil, że te instytucje (...) stanowiq wyraz woli Bożej (EinE 90).

Punktem wyjścia chrześcijańskiej nauki o malżeństwie i rodzinie pozostaje zawsze osoba ludzka. To wlaśnie ona znajduje się u podstaw przymierza malżeńskiego przez wyrażenie nieodwolalnej osobistej zgody (KDK 48). Potwierdzona w ten sposób wolność decyzji jest wyrazem podmiotowości czlowieka oraz jego osobowej godności, co tak jednoznacznie akcentuje antropologia chrześcijańska. Zatem personalistyczna wizja czlowieka i jej osadzenie w zbawczym planie Boga posiada istotne znaczenie dla zrozumienia małżeństwa jako prawdziwej wspólnoty życia i milości (KDK 48) oraz odczytania zamyslu Bożego odnośnie do jego podstawowych funkcji i zadań.

\footnotetext{
${ }^{25}$ Antropologia relacyjna ma na celu odkrycie relacji z drugim czlowiekiem i odejście od ciasnej koncepcji jednostki jako podmiotu skoncentrowanego na sobie i kierujacego się tylko wlasnym interesem (V. Poss enti: Przemiana antropologiczna $i$ demokracja. Tłum. T. Ż eleźnik. „Społeczeństwo". R. 14: 2004 nr 4-5 s. 721.
} 
Widoczne w sposób wyrazisty przemiany spoleczne, kulturowe i religijne na Starym Kontynencie oraz w skali calego świata odzwierciedlają się również w modelu malżeństwa i rodziny. Wspomniane przemiany maja związek z przejściem od spoleczeństwa tradycyjnego do nowoczesnego (a nawet ponowoczesnego). Instytucję malżeństwa, a w konsekwencji rodzicielstwa, rozumie się tutaj nie jako naturalny etap życia czlowieka, ale jako jeden spośród wielu potencjalnych wyborów życiowych. Efektem jest spadek populacyjny przy równoczesnym wzroście, dzięki osiagnięciom współczesnej medycyny, dlugości życia ludzkiego. W demografii zjawisko to wyjaśnia teoria przejścia demograficznego. Teoria ta glosi wyrównywanie się poziomu narodzin i zgonów. Tymczasem zachodzące w Europie przemiany w strukturze rodziny wskazuja na zjawisko tzw. drugiego przejścia demograficznego, którego cechami charakterystycznymi są: wzrost poziomu życia, wykształcenia, bezpieczeństwa socjalnego, autonomii, indywidualizmu, uczestnictwa kobiet w życiu spolecznym, wolności. Równocześnie zaczyna dominować pogląd, że każde dziecko, a tym bardziej kolejne nie tylko ogranicza swobode podejmowanych przez jednostkę wyborów życiowych, ale także utrudnia karierę zawodowa i staje na przeszkodzie życiowego samozrealizowania. Zjawisko drugiego przejścia demograficznego wskazuje zatem na spoleczną akceptację bezdzietności, a w skutkach prowadzi do spadku populacyjnego (większa liczba zgonów w stosunku do narodzin). Stąd wiele państw Europy stało się w ostatnich latach państwami wymierającymi ${ }^{26}$.

Wspólczesny kryzys rozumienia malżeństwa i rodziny stanowi zatem szczególne wyzwanie dla Kościola. W uksztaltowanej przez chrześcijaństwo kulturze europejskiej podstawę rodziny stanowi malżeństwo monogamiczne. W tym kontekście palącą koniecznością staje się podjęcie na nowo misji ewangelizacji rodziny, by z jednej strony przezwyciężyć nagminne wręcz lekceważenie i ośmieszanie wartości nierozerwalności malżeństwa oraz lekkomyślność, z jaka dzisiaj często mlodzi ludzie podchodzą do tej instytucji, stawiając na pierwszym miejscu udane partnerstwo niż sakramentalny związek, a z drugiej strony uwrażliwić małżonków chrześcijańskich na rozmaite pulapki cywilizacyjne, które im zagrażają i wystawiają na poważną próbę $e^{27}$. 1119.

${ }^{26}$ Por. J. B a li c ki: Rodzina. W: Stownik spoteczny. Red. B. S z la c ht a. Kraków 2004 s.

${ }^{27}$ Warto w tym miejscu zapoznać się z zagrożeniami wspólczesnej rodziny podanymi przez S. Wielgusa. Zalicza on do nich: Prawo do aborcji [...]. Różnego rodzaju pomografię i przemoc, niszczqce psychike $i$ charaktery mlodych zwlaszcza ludzi [...]. Dechrystianizację, neopoganizm $i$ calkowita sekularyzacje życia publicznego i prywatnego, która sprawia, że religia, wraz z jej nie dajacymi się niczym zastapić wartościami, przestaje się liczyć nie tylko w życiu narodów, lecz także rodzin i jednostek [...]. Konsumpcjonizm i hedonizm, nakręcany i potegowany przez pozbawiona jakichkolwiek skrupulów reklamę, zamykajacy wiele wspólczesnych rodzin wylacznie w sferze pieniadza i nienasyconego glodu rzeczy. Odrzucenie tradycji - moralnych, religijnych i narodowych - które prowadzi do duchowego samobójstwa rodzin i narodów [...]. Antyrodzinne prawo- 
Duszpasterska dzialalność Kościola, biorąc pod uwagę kryzys malżeństwa i rodziny wywolany przeobrażeniami cywilizacyjnymi oraz uwzględniając sugestie Jana Pawla II zawarte w Ecclesia in Europa, powinna zatem zmierzać do:

- pogłębienia teologii i duchowości malżeństwa i rodziny, z podkreśleniem wartości sakramentalnej godności malżeństwa;

- głoszenia prawdy o rodzinie opartej na nierozerwalności malżeństwa jako związku mężczyzny i kobiety;

- podkreślenia niepowtarzalnej wspólnoty duchowej wytwarzanej przez wszystkich czlonków danej rodziny;

- poszukiwania dróg urzeczywistniania prawdziwej solidarności międzypokoleniowej w rodzinie (por. EinE 91) 2 $^{28}$.

Realizacja wymienionych zadań powinna dokonywać się w ramach duszpasterstwa młodzieży i duszpasterstwa rodzin poprzez kursy przedmalżeńskie, katechezę dla młodzieży i parafialną katechezę dla doroslych. Skuteczną służebną pomocą na rzecz rodziny może okazać się przybliżanie treści połączone z poglębiona naukowa refleksją nad wypracowanymi przez Urząd Nauczycielski Kościoła następującymi określeniami małżeństwa i rodziny: sanktuarium życia (CA 39), wspólnota życia i milości (KDK 48), kolebka życia i milości (ChL 40), domowe sanktuarium Kościola (DA 11), Kościót domowy (KK 11), szkola bogatszego czlowieczeństwa (KDK 52), matka i żywicielka wychowania (KDK 61), naturalna i podstawowa szkola wiary (ChL 62), pierwsza szkola apostolstwa (DA 30), pierwsza plaszczyzna spolecznego zaangazowania (ChL 40), pierwsza szkola cnót spolecznych (DWCH 3), pierwsza i żywotna komórka spoleczeństwa (DA 11), pierwsza i podstawowa komórka ,ekologii ludzkiej” (CA 39).

Kościól, dostrzegając niezastapioną rolę rodziny w gloszeniu Ewangelii, w procesie wychowania i edukacji, wspiera tę instytucję oraz broni ją przed wspólczesnymi zagrożeniami, nie tracạ z pola widzenia samotnych matek, malżonków żyjących w separacji, ludzi rozwiedzionych i opuszczonych dzieci.

\section{Dowartościowanie duszpasterskiej troski o mlodzież}

Papież Jan Pawel II, postulując potrzebę rzetelnej formacji ludzkiej i chrześctjańskiej w odniesieniu do mlodzieży, zachęcil Kościól w Europie do podjęcia i realizacji zadania wychowania mlodych do wiary. Istotna rolę w tym procesie powinno odegrać odnowione duszpasterstwo mlodzieży (EinE 61).

dawstwo w bardzo wielu krajach, destabilizujace rodzine, ulatwiajace jej rozklad, zubożajace ja ekonomicznie (S. W i e $1 \mathrm{~g}$ u s: Rodzina wobec wspólczesnych zagrożeń..., dz. cyt., s. 170-171).

${ }^{28}$ Por. także J a n P a we 1 I I: Trzeba budować solidarność między pokoleniami. Przemówienie do uczestników sesji plenarnej Papieskiej Akademii Nauk Spolecznych (30. IV. 2004). „L'Osservatore Romano". Wydanie polskie. R. 25: 2004 nr 7-8 s. 17; E. R u sin: Rodzina. W: Encyklopedia nauczania spolecznego Jana Pawla II. Red. A. Z w o l iń s k i. Radom 2003 s. 429. 
Organizowane z inicjatywy Jana Pawla II od 1985 roku Światowe Dni Młodzieży sa niezwykle trafnym przedsięwzięciem duszpasterskim, które z jednej strony podkreśla stalą potrzebę dowartościowania tej kategorii wiekowej w dzialalności Kościola, a z drugiej strony staje się wyjściem naprzeciw oczekiwaniom mlodzieży, czego niezbitym dowodem jest niespotykany wręcz entuzjazm mlodych ludzi, budowanie wspólnoty, dialogu i wzajemnego zaufania przekraczającego granice państw i kontynentów.

W podobnym duchu należy spojrzeć na zdominowane w znacznym stopniu przez młodzież piesze pielgrzymki podążające na przelomie lipca i sierpnia na Jasną Górę, czy też organizowane od 1997 r. w wigilię uroczystości Zesłania Ducha Świętego spotkania na polach lednickich. Fenomen wspomnianych inicjatyw duszpasterskich, będących przecież potężnym środkiem ewangelizacji oraz liczny w nich udzial młodzieży świadczy o jednym, mlody czlowiek odkrywa pragnienie bycia we wspólnocie i potrzebę wyjścia z osamotnienia, odczuwa utajonq wiarę oraz glód absolutu, akceptuje także Ewangelię, jej przeslanie i wartości, a zarazem często nie potrafii zaakceptować tradycyjnych form kultu religijnego, odnosząc się z obojętnością do instytucji „Kościola urzędowego” i oficjalnego nauczania kościelnego magisterium (EinE 61$)^{29}$.

Wchodząc w szczególy zasygnalizowanej problematyki wypada na początku zauważyć, że Jan Pawel II, zwracając się do mlodzieży, najpierw podkreśla w swoich przesłaniach to wszystko, co jest pozytywne w mlodym czlowieku i co budzi prawdziwą nadzieję (mlodzieńczy entuzjazm, idealizm, zapal, radość, poszukiwanie sensu życia, Boga, zachwyt autentycznymi świadkami wiary), a dopiero na drugim miejscu mówi z odwagą o najbardziej niepokojących problemach, których nie boi się nazywać po imieniu, a które dotykają młodego czlowieka i w konsekwencji stają się dla niego poważnym zagrożeniem. Nie można w tym miejscu nie zauważyć zastosowania wlaściwej metody wychowawczej, która polega na dowartościowaniu człowieka i skupieniu uwagi na tym, co jest w nim dobre, by następnie stawiać wymagania i wykazywać błędy. Co więcej, papież zachęca Kościól, mówiąc o potrzebie wychowania młodych do wiary oraz o potrzebie odnowienia duszpasterstwa mlodzieżowego, by pierwszoplanowymi uczestnikami ewangelizacji uczynił wlaśnie ludzi młodych (EinE 62). Ponadto wypada $\mathrm{w}$ tym miejscu wspomnieć o tym, że jedna $\mathrm{z}$ charakterystycznych cech okresu młodości jest fakt poszukiwania konkretnego projektu życia, wedlug którego młody czlowiek pragnie budować swoje przyszłe dorosłe życie. Stąd Ko-

${ }^{29}$ Por. K. P a w l in a: Kondycja duchowa mlodego pokolenia Polaków. W: Glosić Ewangelię nadziei. Program duszpasterski na rok 2004/2005. Katowice 2004 s. 95-97; A. A n d r e s: Różnorodne obrazy Jezusa u mlodzieży wspólczesnej. Thum. L. B a 1 t e r. „Communio”. Wydanie polskie. R. 16: 1996 nr 3 s. 67. 
ściól w swojej misji ewangelizacyjnej musi spotkać się z młodym czlowiekiem, by ukazać mu wlaściwy kierunek życiowej drogi.

Mając to na uwadze, duszpasterska troska Kościola o mlodego czlowieka powinna zatem zmierzać do:

a) rozbudzania, umacniania i pogłębiania wiary poprzez:

- niesienie pomocy w przywracaniu wlaściwego obrazu Boga;

- ukazywanie wartości życia modlitewnego i sakramentalnego;

- oferowanie pomocy w odkryciu Kościola-Wspólnoty;

b) towarzyszenia $\mathrm{w}$ procesie samorealizacji:

- wychowywanie do odpowiedzialnej wolności;

- świadczenie pomocy na rzecz pokonywania lęku młodego czlowieka przed przegrana życiowa;

- edukacja na rzecz kultury spędzania wolnego czasu i podjęcie troski o pożyteczne zagospodarowanie tego czasu;

- wychowanie do wlaściwego odbioru programów telewizyjnych i korzystania z Internetu i multimediów;

c) aktywizowania na rzecz zaangażowania spolecznego i kościelnego ${ }^{30}$.

Nie sposób wymienić wszystkich zadań duszpasterskich dotyczących młodzieży. Należy jednak mieć zawsze na względzie tę prawdę, że Kościól w stosunku do mlodego człowieka pelni zarówno rolę ewangelizacyjna, jak też wychowawcza. Ponadto pastoralny program duszpasterstwa mlodzieży powinien uwzględniać widoczny w polskiej rzeczywistości fakt obecności ogromnej liczby mlodych ludzi na katechizacji szkolnej, przy jednoczesnym stosunkowo dużym procencie absencji na niedzielnej Mszy św. i innych praktykach religijnych.

\section{Dowartościowanie duszpasterskiej troski o bezrobotnych, ubogich i bezdomnych}

Zjawisko bezrobocia, jako problem społeczny, uwidocznilo się wraz z rozwojem przemysłu i nabralo szczególnego znaczenia podczas kryzysów gospodarczych w XIX i XX wieku. Zlożoność i wieloznaczność wspomnianego zjawiska prowadzi do pojawienia się trudności w jednoznacznym i precyzyjnym zdefiniowaniu zarówno samego bezrobocia, jak też osoby bezrobotnej j3. Niezależnie

${ }^{30}$ Szerzej na ten temat zobacz H. T o mas ik: Wychowanie mlodych do wiary. W: Glosić Ewangelie nadziei..., dz. cyt., s. 105-132; A. D1u g o s z: Duszpasterstwo mlodziezowe wobec nowych wyzwań. W: Glosić Ewangelię nadziei..., dz. cyt., s. 132-139.

${ }^{31} \mathrm{~W}$ ekonomii bezrobocie określa się jako stan nierównowagi na rynku pracy (pomiędzy podaża pracy a popytem pracy), będącej skutkiem utrzymywania się plac nominalnych powyżej poziomu zapewniającego równowagę. W socjolog ii bezrobocie rozumie się jako stan, w którym 
jednak od przyjętej definicji warto uzmyslowić sobie prawdę, że bezrobocie uważane jest za naruszenie jednego z podstawowych praw osoby ludzkiej - prawa do pracy. Ponadto wagę bezrobocia podkreśla także fakt, że jest to poważny problem natury ekonomicznej, politycznej, spolecznej, moralnej i psychologicznej, rodzący wiele negatywnych skutków ${ }^{32}$. Ów problem stanowi dziś w Europie groźna klęskę i plage spolecznq (LE 18, EinE 87), stąd Jan Pawel II postuluje poważne podejście do zjawiska bezrobocia (EinE 87). Już wcześniej w encyklice Laborem exercens uznal je za przejaw głębokiej niesprawiedliwości i nierówności spolecznej (por. LE 1).

Jako novum w polskiej rzeczywistości spolecznej od 1989 roku, a zarazem jako pewnego rodzaju symbol gospodarki wolnorynkowej bezrobocie nie mogło nie znaleźć miejsca w duszpasterskiej działalności Kościoła w Polsce. Utrata bowiem pracy i niemożność jej znalezienia powodują frustrację, lęk, depresję, poczucie zawodu życiowego i poniżenia osobowej godności, a także stanowią jeden z podstawowych czynników dezintegrujacych rodzinę. Majac to na uwadze biskupi polscy w oparciu o nauczanie społeczne Kościoła wydali ważny list spoleczny na temat bezrobocia, pt. $W$ trosce o nowq kulturę życia i pracy (6 października 2001 r.), w którym dokonali nie tylko moralnej oceny tego bolesnego zjawiska, ale także podali kilka propozycji ogólnych odnoszących się do przezwyciężenia go.

Niemniej ważnym okazal się głos arcybiskupa Damiana Zimonia, który w liście, pt. Kościól katolicki na Ślasku wobec bezrobocia (19 marca 2001 r.) wskazal konkretne postulaty o charakterze etycznym. Metropolita katowicki sprowadzil je do trzech grup:

- wskazania dla odpowiedzialnych za ksztalt życia publicznego,

- wskazania dla dotkniętych bezrobociem i ich rodzin,

- wskazania dla wspólnot i duszpasterzy ${ }^{33}$.

Potrzeba podjęcia konkretnych zaproponowanych działań w celu przezwyciężenia bezrobocia wynika z prawdy, że praca stanowi podstawowe dobro czlo-

jednostki zdolne do pracy i zglaszające gotowość jej podjęcia, ze względu na brak pracy, pozostaja w bezczynności zawodowej. W katolickiej nauce społecznej bezrobocie to sytuacja gospodarcza i społeczna, w której pewna część pracowników pozbawiona jest zatrudnienia. Por. $\mathrm{M}$. D u da: Bezrobocie. W: Encyklopedia nauczania spolecznego Jana Pawla II..., dz. cyt., s. 49; W. P i w o w a r sk i: Bezrobocie. W: Stownik katolickiej nauki spotecznej. Red. W. P i wow a r ski. Warszawa 1993 s. 19-20; M. R a c z y ń s k i: Bezrobocie. W: Slownik spoleczny..., dz. cyt., s. 44; J. B. S o b c z a k: Bezrobocie. W: Encyklopedia socjologii. T. 1. Warszawa 1998 s. 64-65.

${ }^{32}$ Warto zapoznać się z szeroka analizą negatywnych skutków bezrobocia podaną przez M. D u d ę w pracy: Problematyka bezrobocia i jej spoleczno-duchowych skutków $w$ świetle katolickiej nauki spolecznej. Kraków 2002 s. 117-167.

${ }^{33}$ D. Z i m o ń: Kościól katolicki na Ślasku wobec bezrobocia. W: Pochylmy się nad bezrobociem. Katowice 2002 s. 46-52. 
wieka, a prawo do niej jest fundamentalnym prawem osoby ludzkiej. Wypada ponadto $\mathrm{w}$ tym miejscu uzmyslowić sobie, że właśnie zjawisko braku pracy przynosi szkodę osobie pozbawionej pracy, dotkliwie uderza w życie rodzinne, prowadząc do jego destabilizacji, sprzyja tworzeniu się postaw antyspolecznych, rodzi rozmaite patologie spoleczne.

W tej sytuacji Kościól, nie mogąc pozostać obojętnym, obejmuje pastoralną troską bezrobotnych na dwóch plaszczyznach: dzialania i nauczania. Po pierwsze, Kościół podejmuje rozmaite akcje doraźne i dziela charytatywne o charakterze dobroczynnym na rzecz bezrobotnych i ich rodzin. Po drugie, Kościól, głoszac zasady doktryny społecznej, pragnie nie tylko przedstawić poglębiona refleksję na temat bezrobocia i jego skutków, ale także podkreśla potrzebę uwzględniania zasad moralnych w etycznym rozwiązaniu problemu ${ }^{34}$.

Analiza braku pracy i roli Kościola w przezwyciężaniu tego zjawiska prowadzi do zwrócenia uwagi na jeszcze jeden bardzo istotny fakt obecny w polskiej rzeczywistości w odniesieniu do bezrobocia. Niepokojącym bowiem zjawiskiem jest duży procent ludzi mlodych (absolwentów różnych szkól) dotkniętych brakiem zatrudnienia. Wagę problemu podkreśla fakt, iż chodzi tutaj o kategorię ludzi zdolnych do pracy, będacych w twórczym okresie swojego życia i jednocześnie zdolnych do przekwalifikowania wlasnych umiejętności i zawodu. Drugim bolesnym rysem polskiego bezrobocia jest zwiększająca się liczba osób pozostających bez pracy dłużej niż dwanaście miesięcy, czyli doświadczających bezrobocia dhugotrwalego ${ }^{35}$.

Jako bolesny problem spoleczny bezrobocie staje się wielkim wyzwaniem duszpasterskim dla Kościola. Tym większym, że konsekwencją braku zatrudnienia jest ubóstwo, a niekiedy nawet bezdomność. Zadaniem Kościoła jest zatem przywracanie nadziei wszystkim bezrobotnym, bezdomnym i ubogim, albowiem jak podkreślil Jan Pawel II: Milość preferencyjna wobec ubogich jest koniecznym wymiarem chrześcljanskiej egzystencji $i$ slużby Ewangelii (...), a wartość osoby jest niezależna od sytuacji ekonomicznej, kulturowej, spolecznej, w jakiej się znajduje (EinE 86).

\footnotetext{
${ }^{34}$ Por. A. W u wer: Bezrobocie jako wyzwanie dla solidarności spolecznej. W: Katolicka nauka spoleczna. Podstawowe zagadnienia z zycia gospodarczego. Red. J. K u p n y, S. F e l. Katowice 2003 s. 56.

${ }^{35}$ Por. M. K a b a j: Elementy programu przeciwdzialaniu bezrobociu. W: Polityka spoleczna. Stan i perspektywy. Red. J. A u le y t ner. Warszawa 1995 s. 156-160.
} 


\section{Popularyzowanie nauki spolecznej Kościola i zachęcanie do podejmowania dzialań $w$ jej duchu ${ }^{36}$}

Wypada także podkreślić wagę nauki społecznej Kościoła w ksztaltowaniu etosu przyszlej zjednoczonej Europy. Katolicka nauka spoleczna w wizji papieskiej jest bowiem jednym z ewangelizacyjnych narzędzi Kościola i stanowi istotnq część orędzia chrześcijańskiego (SRS 41; CA 4), a mając ścisly związek z godnością osoby ludzkiej może być zrozumiala także przez tych, którzy nie podzielaja wiary w Boga (EinE 99). Ta wlaśnie dziedzina wiedzy może stać się zatem punktem przelamywania barier i przezwyciężania wzajemnych nieufności, prowadząc tym samym do dialogu i porozumienia.

Kościól, dążąc do osiagnięcia celu ponaddoczesnego i ponadczasowego, jakim jest zbawienie czlowieka, nie może abstrahować od spolecznego wymiaru ludzkiej egzystencji. Prowadząc ludzi do zbawienia musi brać pod uwage ich ziemskie życie, osadzone w ramach konkretnego czasu i określonych uwarunkowań społecznych, politycznych, gospodarczych i kulturowych, a do takich bez wạtpienia należy zaliczyć dokonujący się proces integracji Starego Kontynentu. Kościól, glosząc Ewangelię, pragnie nieść pomoc w urządzaniu życia spolecznego. Ucząc zasad moralnych, ksztaltując ludzkie sumienie oraz formując czlowieka na wzór Chrystusa w jego życiu osobistym, wplywa tym samym na ksztalt życia spolecznego ${ }^{37}$.

Oddzialywanie Kościola katolickiego na rzeczywistość spoleczną idzie także drugą droga, w ramach funkcji profetyczno-krytycznej. Z jednej strony dostarcza on, wlaśnie poprzez nauczanie spoleczne i wypracowane przez nie zasady (pomocniczości, solidarności, dobra wspólnego), pozytywnych wskazań dotyczacych budowania ladu społecznego, zaprowadzenia sprawiedliwości, czy rozwiazywania nabrzmiałych problemów społecznych, a z drugiej wysuwa ostrzeżenia, piętnuje zlo oraz wskazuje na błędy w postaci zaistnienia sytuacji krzywdy, wyzysku, czy niesprawiedliwości. Stąd przed Kościołem pojawia się wymóg etycznej oceny wszystkich podstawowych dziedzin życia ludzkiego, co nie oznacza przekroczenia przez Niego właściwego zakresu kompetencji. Trzeba przy tym pamiętać, że Kościól nie wskazuje konkretnych rozwiązań ustrojowych, lecz jedynie formułuje zasady i wskazania będące podstawą służby dla dobra każdego czlowieka $^{38}$.

\footnotetext{
${ }^{36}$ Punkt ten stanowi część mojego artykułu pt. Rola i zadania chrześcijan w procesie budowania etosu Europy. „Spoleczeństwo”. R. 14: 2004 nr 3 s. 534-536.

${ }^{37}$ Por. J. Ma j k a: Katolicka nauka spoleczna, Studium historyczno-doktrynalne. Rzym 1987 s. 6.

${ }^{38}$ Por. T. G $\nmid$ u s z a k: Akcja Katolicka miejscem formacji duchowej i spolecznej. „Spoleczeństwo". R. 8: 1998 nr 1 s. $157-158$.
} 
Podkreślając ważność misji społecznej Kościola $w$ budowie lepszego świata Jan Pawel II w adhortacji Ecclesia in Europa nie tylko raz jeszcze zaapeluje o podjęcie dzialań w celu przezwyciężenie nieznajomości katolickiej nauki spolecznej także w szerokich kręgach chrześcijan, ale wręcz wezwie do podjęcia troski o zgłębianie treści tej nauki i szerzenia jej zasad w życiu. Wymaga tego napisal papież - nowa, tworzqca się Europa, która potrzebuje ludzi wychowanych zgodnie z tymi wartościami, gotowych pracować nad urzeczywistnianiem dobra wspólnego. W tym celu jest konieczna obecność świeckich chrześcijan, którzy pelniq̨ różne odpowiedzialne funkcje w życiu spolecznym, gospodarce, kulturze, shuzbie zdrowia, oświacie i polityce, postępowaliby tak, by móc zaszczepić w nim wartości Królestwa Bożego (EinE 99).

Na zakończenie wypada podkreślić jeszcze dodatkowo te płaszczyzny życia, na których nieodzowna jest wręcz obecności chrześcijan w zlaicyzowanych, konsumpcyjnie i doznaniowo nastawionych oraz przepelnionych duchowa pustką $i$ znudzeniem spoleczeństwach Europy. Do plaszczyzn tych zaliczyć należy w dziedzinie życia narodowego promowanie chrześcijańskiego etosu pracy oraz kierowanie się wypracowanymi przez nauczanie społeczne Kościola zasadami spolecznymi, a w dziedzinie życia osobistego dostarczanie motywów nadziei i przetrwania, jak również przezwyciężanie postaw eurosceptycznych. Chrześcijanin nie może bowiem zapomnieć o odczytywaniu znaków czasu, ani też zaprzepaścić wiary w Bożą Opatrzność.

Kościół, realizując dzieło ewangelizacji świata głosi w swoim posłannictwie Chrystusa Kaplana, Proroka i Króla. Podkreśla jednocześnie wartość wiary i dziedzictwa chrześcijańskiego. W wypelnianiu tego zadania na Starym Kontynencie nie może nie uwzględnić inspirujacych słów papieskich: Trzeba, aby w Europie wzrosla znacznie świadomość jej duchowego dziedzictwa (EinE 120).

Obecne bowiem czasy z nową kulturą, często sprzeczną z duchem Ewangelii, stają się naglącym wyzwaniem dla Kościola XXI wieku. Co więcej, w tych wlaśnie nowych czasach wylania się potrzeba odkrycia bogatego dziedzictwa i sensu wiary chrześcijańskiej, o co wielokrotnie apelowal Jan Paweł II.

Mając to na uwadze oraz uwzględniając zaprezentowana w opracowaniu problematykę, wypada zaproponować kilka postulatów, które mogą shużyć pomocą w lepszym zrozumieniu zmian zachodzących we wspólczesnym świecie. Trzeba uzmysłowić sobie prawdę, że wszelkie dokonujące się przemiany w życiu spolecznym, kulturowym i religijnym nie pozostaja bez wplywu na życie konkretnej osoby ludzkiej. 
Pragnąc zatem twórczo wlączyć się w dzielo budowania Europy ducha potrzeba uwzględnić następujące postulaty:

Po pierwsze, podkreślić potrzebę wlaściwego rozeznania zlożonej sytuacji wspólczesnego świata. Postulat ten wydaje się być ważnym, ponieważ brak orientacji oraz niedostateczne rozumienie przyczyn zrodzenia się błędnych teorii i ideologii grozi falszywą oceną rzeczywistości, co w konsekwencji prowadzić może do blędnego spojrzenia na czlowieka oraz deformacji życiowych idealów lub ich calkowitego odrzucenia.

Po drugie, w sytuacji kryzysu cywilizacji europejskiej rodzi się potrzeba dowartościowania, cennej także dla życia społecznego, misji Kościoła i dziedzictwa chrześcijańskiego. Dziedzictwo to, jak zauważyl Jan Pawel II, nie należy wylqcznie do przeszlości, ale jest programem na przyszlość, który należy przekazać nadchodzqcym pokoleniom, gdyż jest źródlem życia ludzi i narodów, którzy wspólnie będa ksztaltowali kontynent europejski (EinE 120).

Po trzecie, podkreślić niezastapioną i służebną rolę Kościoła w propagowaniu poprawnej koncepcji osoby ludzkiej oraz prawdy o wartości sakramentalnego małżeństwa i rodziny. Ponadto w pastoralnej dzialalności Kościół nie może pominąć, zwlaszcza dzisiaj, mlodzieży, bezrobotnych i ubogich.

Po czwarte, w realizacji duszpasterskiej działalności pomoca moga okazać się zasady wypracowane przez katolicka naukę spoleczną. Dyscyplina ta, inspirując chrześcijan do dzialania, pomaga jednocześnie dostrzec istotny związek między wiarą wyznawaną a zachowaniami w różnych dziedzinach życia i aktywności publicznej. 
